\title{
13. ASH LAYERS INTERLA YERED WITH THE SEDIMENTS OF HOLES 407 AND 408, IPOD LEG 49
}

\author{
Jacques Varet, B.R.G.M., Dt Géothermie, Orleans, France \\ and \\ Nicole Metrich, Université de Paris-Sud, Orsay, France
}

\section{INTRODUCTION}

Several layers of volcanic ash were recovered from Holes 407 and 408 , southwest of Iceland. This paper provides a description of these layers, and compares their mineralogy and the chemistry of the glasses with Icelandic magmas (Figure 1).

\section{PETROGRAPHY OF THE VOLCANIC PRODUCTS}

\section{Clastic Products and Ashes in Hole 407}

Clastic fragments of volcanic origin, observed in most of the sediments recovered in Hole 407, are glassy fragments that are generally pale brown and frequently palagonitized or chloritized (Figure 2). The minerals associated with these fragments are feldspar, pyroxene, magnetite, altered olivine, and (rarely) amphibole or biotite. Fragments are angular in shape and range in size from 0.1 to $1 \mathrm{~mm}$. Volcanogenic fragments are particularly abundant in the Pleistocene calcareous sandy mud, where at least five ash layers were found. Major ash layers also occur in Pliocene sediments at $86,87,88$, and 90 meters, and in the middle Miocene at 175, 208, and 215 to 224.5 meters. The 208 -meter layer is $30 \mathrm{~cm}$ thick (Sample 407-23-1, $18 \mathrm{~cm}$ ); the 215-meter layer is $120 \mathrm{~cm}$ thick and consists of a basaltic ash (Sample 407-24-1, $40 \mathrm{~cm}$ to $407-24-2,120 \mathrm{~cm}$ ); the 221.2-meter layer is $15 \mathrm{~cm}$ thick (Sample 407-24-5, 20 $\mathrm{cm}$ ); and the layer at 224 meters is $60 \mathrm{~cm}$ of altered basaltic glass (Sample 407-24-6, 90-150 cm). In the 282- to $301-$ meter interval, a volcaniclastic layer (15\% basaltic glass, $30 \%$ basaltic fragments), contains abundant Oligocene sediment.

Petrographic study of the samples shows that most of the layers are pyroxene-plagioclase from an olivine-plagioclase-pyroxene porphyritic basalt. The permanence of pyroxene indicates a tholeitic composition typical of the mid-ocean ridge. Layers located in the 86- to 90-meter interval differ from the others by the abundance $(90 \%)$ of an aphytic colorless glass with a low refractive index, which corresponds to a more silicic composition. Fragments of brown basaltic glass are also present in this interval. The 175-meter layer contains the association of brown and colorless glasses (Figure 3 ).

\section{Clastic Products and Ashes in Hole 408}

Clastic fragments of volcanic origin and ash layers are nearly as abundant in Hole 408 as in Hole 407. Although the basement is younger in Hole 408, the thickness of sediments drilled at this site is very similar to that at Hole 407 .

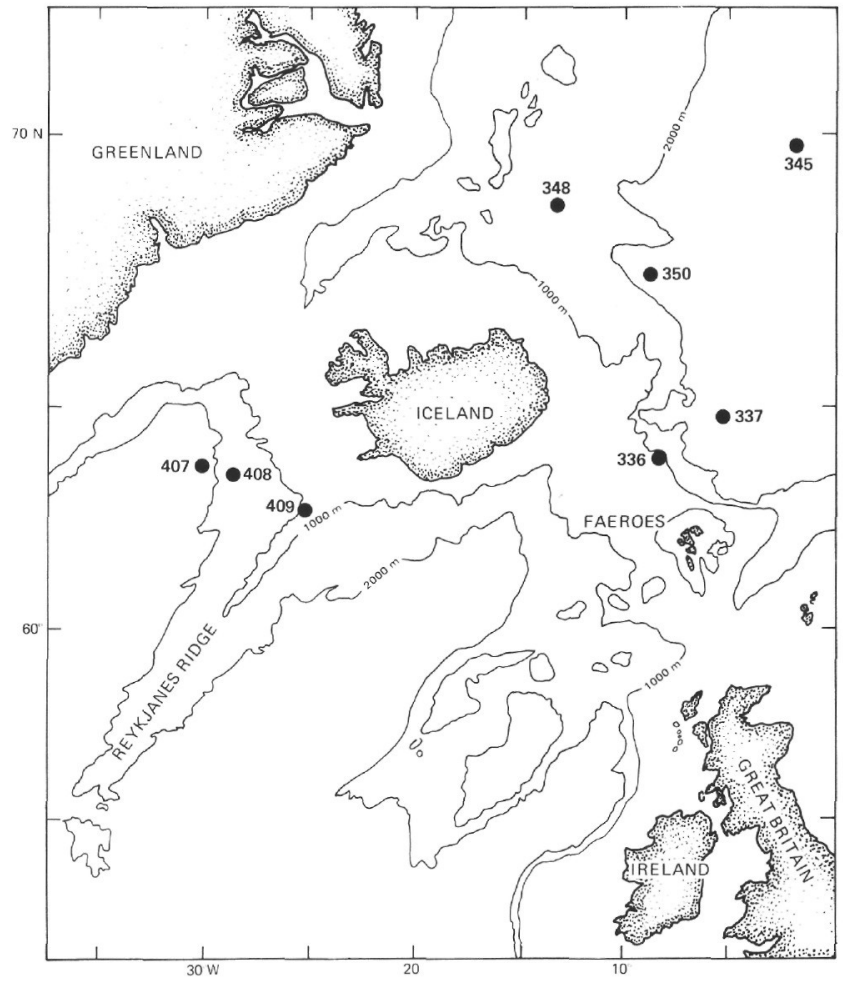

Figure 1. Locations of Sites 407 and 408; other DSDP sites are also shown.

Numerous ash layers occur at various levels, as described below.

In the first 10 meters, an ash-rich calcareous, sandy mud occurs, bearing 10 to 25 per cent volcanogenic fragments. Two glasses of different colors and refractive indices are present in this layer: a brown basaltic glass of high refractive index and a colorless rhyolitic glass. A few crystals of alkali feldspar, plagioclase, and quartz are associated with the colorless glass.

A similar association of two glasses occurs at the 36.5-meters depth (Sample 408-4-5, $85 \mathrm{~cm}$ ) and at 147 meters (Sample 408-4-5, $147 \mathrm{~cm}$ ). These two thin layers are partly altered, and the basaltic glass is the more affected. A thin layer of basaltic glass occurs at 39 meters (Sample 39-5-1, $95 \mathrm{~cm}$ ). It overlies an ash layer (Sample 408-5-2, 45 $\mathrm{cm})$ composed of a mixture of basaltic $(80 \%)$ and rhyolitic $(20 \%)$ glasses, both aphyric (Figure 4$)$.

At 115 meters, a layer of basaltic glass contains fresh and altered fragments (Sample 408-13-1, $100 \mathrm{~cm}$ ). No 

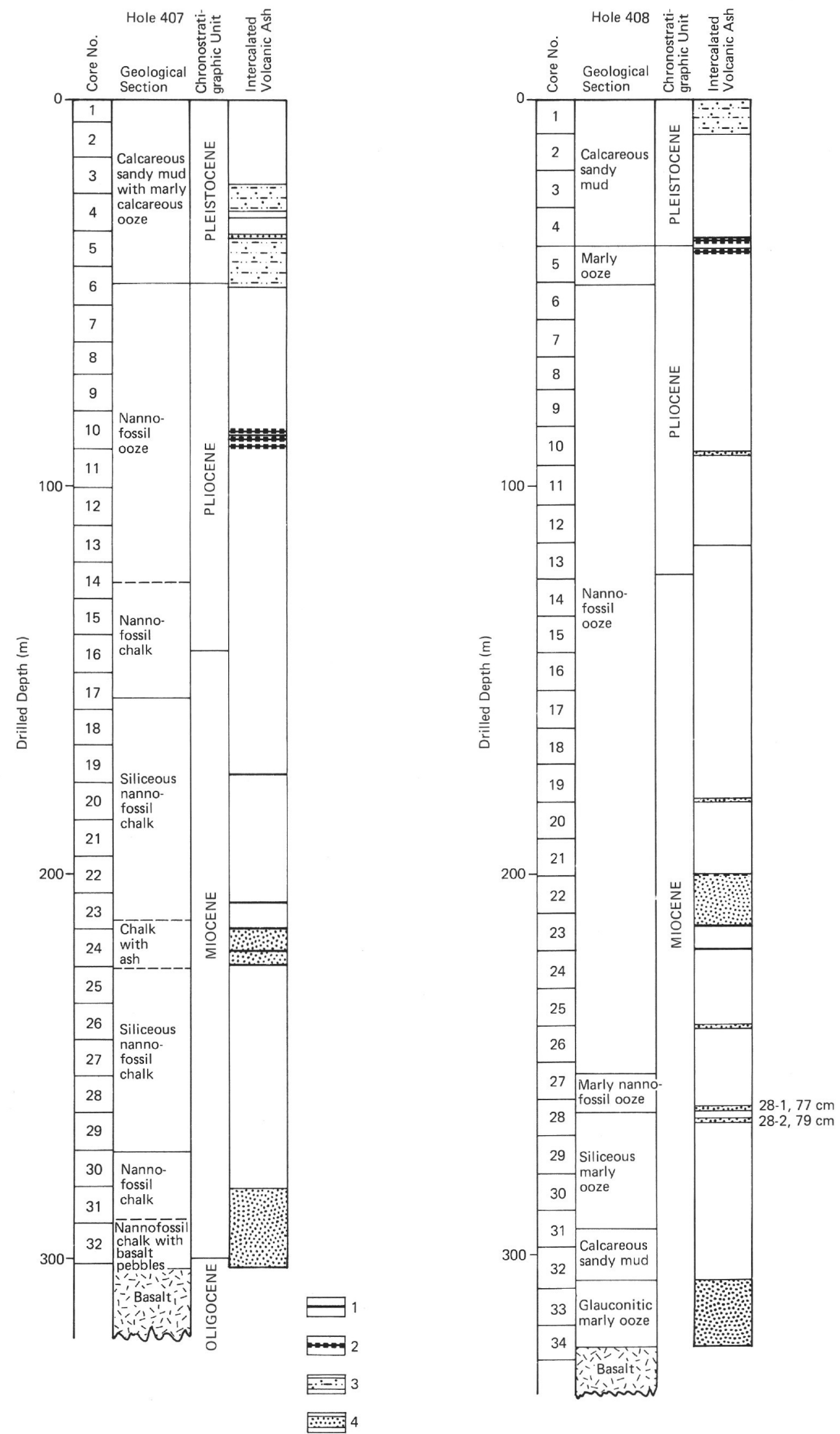

Figure 2. Compared lithostratigraphic sections of Holes 407 and 408. Observed ash layers are schematically indicated (1) basaltic ash layer; (2) ash layer with rhyolitic glass; (3) sediment rich in glass and clay (altered glass); (4) sediment rich in volcanic glass. 


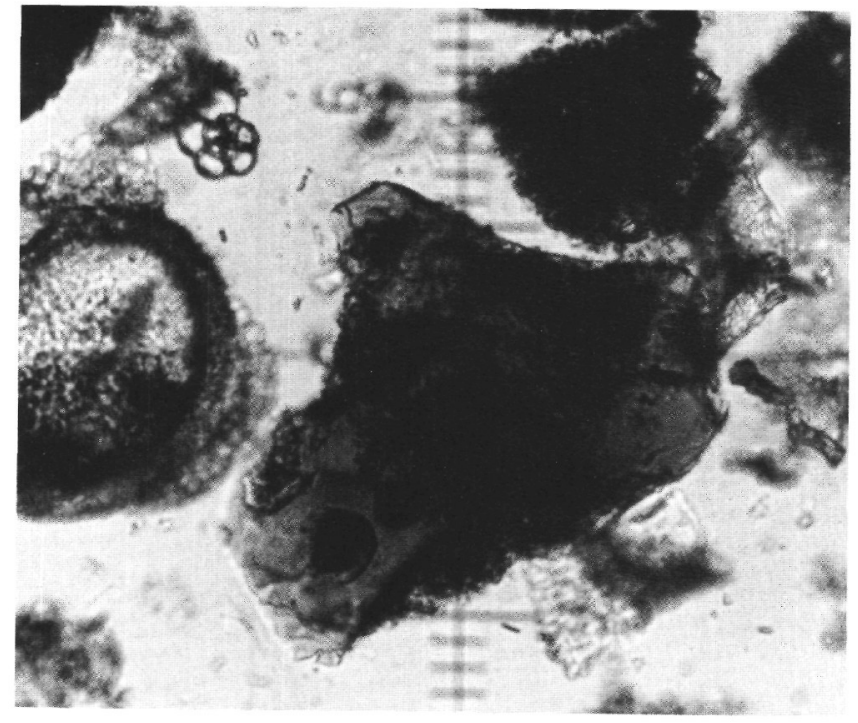

Figure 3. Fragment of basaltic glass in Hole 407. Approximate length $1 \mathrm{~mm}$.

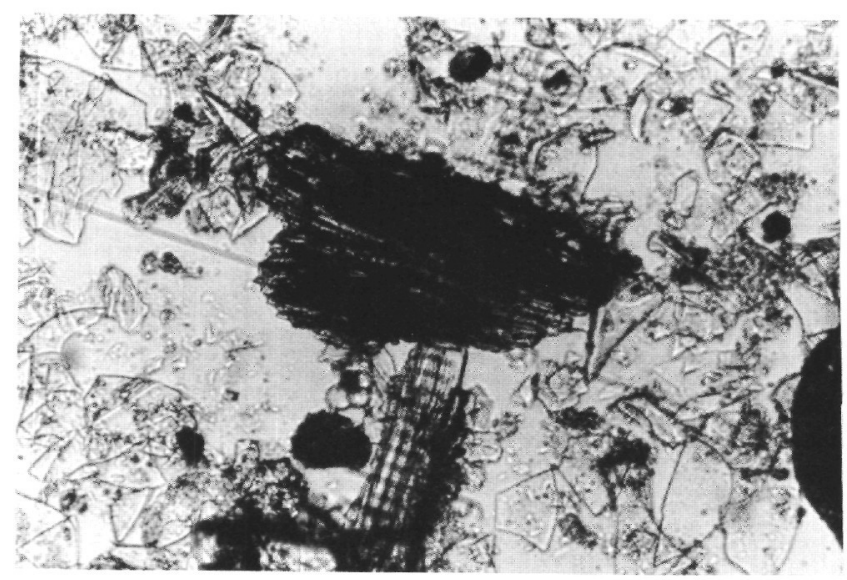

Figure 4. Fragment of thin, low-refractive-index colorless glass fragments associated with layer fibrous basaltic pumice fragments in Hole 407.

important ash layer is present in the section until the 199.5to 218.5-meter interval, where at least four major ash layers occur.

A mixture of nearly equal proportions of basaltic and rhyolitic aphyric glasses was removed from the core catcher of Core 21. These glasses were analyzed by microprobe (Table 1). Numerous dark sand balls occur in the nannofossil ooze in the 200- to 209-meter interval. They probably result from reworking of a volcanic ash-fall. A thin layer of basaltic ash is present at 212.5 meters sub-bottom (Sample 408-23-3, $52 \mathrm{~cm}$ ). It is a fresh brown aphyric glass. A similar layer occurs at 218.5 meters.

In addition to these thin volcaniclastic products, an angular block of alkali granite was recovered at 209 meters (Sample 408-23-1, 5-7 cm). This granite is composed of euhedral crystals of 20 per cent oligoclase $\left(A n_{12}\right)$ and 40 per cent sanidine, rich in glassy inclusions. A small amount of syncrystallized aegirine-augite and sodic amphibole
TABLE 1

Microprobe Analysis of Rhyolite Glasses Intercalated in the Sediments From Holes 407 and 408

\begin{tabular}{|c|c|c|c|c|c|c|c|c|c|}
\hline \multicolumn{10}{|c|}{ Sample $407-10-3,50 \mathrm{~cm}$} \\
\hline & $\begin{array}{l}\text { Fragment } 1 \\
(\%)\end{array}$ & $\begin{array}{c}2 \\
(\%)\end{array}$ & $\begin{array}{c}3 \\
(\%)\end{array}$ & $\begin{array}{c}4 \\
(\%)\end{array}$ & $\begin{array}{c}5 \\
(\%)\end{array}$ & $\begin{array}{l}6 \\
(\%)\end{array}$ & $\begin{array}{c}7 \\
(\%)\end{array}$ & $\begin{array}{c}8 \\
(\%)\end{array}$ & $\begin{array}{c}\text { Sample } \\
408-21, \mathrm{CC}\end{array}$ \\
\hline $\mathrm{SiO}_{2}$ & 69.78 & 70.50 & 69.75 & 71.44 & 69.54 & 70.05 & 70.10 & 69.83 & 69.17 \\
\hline $\mathrm{TiO}_{2}$ & 0.21 & 0.24 & 0.21 & 0.17 & 0.16 & 0.17 & 0.17 & 0.24 & 0.22 \\
\hline $\mathrm{Al}_{2} \mathrm{O}_{3}$ & 12.22 & 12.15 & 12.27 & 12.24 & 12.22 & 12.18 & 12.07 & 12.29 & 11.78 \\
\hline $\mathrm{Fe}_{2} \mathrm{O}_{3}$ & 1.50 & 1.50 & 1.50 & 1.50 & 1.50 & 1.50 & 1.50 & 1.50 & 1.50 \\
\hline $\mathrm{FeO}$ & 1.53 & 1.47 & 1.52 & 1.47 & $1.52^{\circ}$ & 1.61 & 1.39 & 1.44 & 2.58 \\
\hline $\mathrm{MnO}$ & 0.11 & 0.08 & 0.09 & 0.08 & 0.07 & 0.07 & 0.07 & 0.09 & 0.11 \\
\hline $\mathrm{MgO}$ & 0.01 & 0.01 & 0.01 & 0.01 & 0.01 & 0.01 & 0.01 & 0.01 & 0.04 \\
\hline $\mathrm{CaO}$ & 0.95 & 1.20 & 1.07 & 1.08 & 1.00 & 0.96 & 1.08 & 1.12 & 1.46 \\
\hline $\mathrm{Na}_{2} \mathrm{O}$ & 3.41 & 4.55 & 4.78 & 4.50 & 3.46 & 4.25 & 4.61 & 4.62 & 4.60 \\
\hline $\mathrm{K}_{2} \mathrm{O}$ & 4.54 & 3.26 & 3.15 & 3.32 & 4.65 & 3.89 & 3.17 & 3.37 & 2.59 \\
\hline $\mathrm{P}_{2} \mathrm{O}_{5}$ & 0.01 & 0.01 & 0.01 & 0.01 & 0.01 & 0.01 & 0.01 & 0.01 & 0.01 \\
\hline \multicolumn{10}{|c|}{ Cation Per Cent } \\
\hline $\mathrm{Si}$ & 69.59 & 69.32 & 68.86 & 69.66 & 69.37 & 69.14 & 69.44 & 68.88 & 68.87 \\
\hline $\mathrm{Ti}$ & 0.16 & 0.18 & 0.16 & 0.12 & 0.12 & 0.13 & 0.13 & 0.18 & 0.16 \\
\hline $\mathrm{Al}$ & 14.36 & 14.08 & 14.27 & 14.06 & 14.36 & 14.17 & 14.09 & 14.29 & 13.82 \\
\hline $\mathrm{Fe}_{3}$ & 1.13 & 1.11 & 1.11 & 1.10 & 1.13 & 1.11 & 1.12 & 1.11 & 1.12 \\
\hline $\mathrm{Fe}_{2}$ & 1.27 & 1.21 & 1.25 & 1.20 & 1.27 & 1.33 & 1.15 & 1.19 & 2.15 \\
\hline $\mathrm{Mn}$ & 0.09 & 0.07 & 0.08 & 0.07 & 0.06 & 0.06 & 0.06 & 0.08 & 0.09 \\
\hline $\mathrm{Mg}$ & 0.01 & 0.01 & 0.01 & 0.01 & 0.01 & 0.01 & 0.01 & 0.01 & 0.06 \\
\hline $\mathrm{Ca}$ & 1.01 & 1.26 & 1.13 & 1.13 & 1.07 & 1.01 & 1.15 & 1.18 & 1.56 \\
\hline $\mathrm{Na}$ & 6.59 & 8.67 & 9.14 & 8.50 & 6.69 & 8.13 & 8.85 & 8.83 & 8.87 \\
\hline K & 5.77 & 4.09 & 3.97 & 4.13 & 5.92 & 4.90 & 4.00 & 4.24 & 3.29 \\
\hline \multicolumn{10}{|c|}{ Normative Per Cent } \\
\hline Qz & 31.74 & 30.61 & 29.20 & 31.40 & 30.84 & 29.72 & 30.65 & 29.34 & 30.36 \\
\hline Or & 28.45 & 20.28 & 19.72 & 20.47 & 29.18 & 24.27 & 19.89 & 21.07 & 16.27 \\
\hline $\mathrm{Ab}$ & 30.59 & 40.52 & 42.84 & 39.72 & 31.09 & 37.96 & 41.40 & 41.34 & 41.36 \\
\hline An & 4.92 & 3.27 & 2.89 & 3.55 & 4.34 & 2.83 & 3.07 & 3.02 & 4.10 \\
\hline Wo & 0.0 & 0.07 & 0.0 & 0.0 & 0.0 & 0.0 & 0.0 & 0.04 & 0.0 \\
\hline *Wo & 0.00 & 1.15 & 1.11 & 0.82 & 0.36 & 0.89 & 1.07 & 1.12 & 1.47 \\
\hline *En & 0.00 & 0.03 & 0.02 & 0.02 & 0.01 & 0.02 & 0.03 & 0.03 & 0.05 \\
\hline${ }^{*} \mathrm{Fs}$ & 0.01 & 1.27 & 1.23 & 0.91 & 0.40 & 0.99 & 1.18 & 1.24 & 1.61 \\
\hline En & 0.03 & 0.0 & 0.00 & 0.01 & 0.02 & 0.01 & 0.00 & 0.0 & 0.06 \\
\hline Fs & 1.51 & 0.0 & 0.22 & 0.47 & 1.11 & 0.66 & 0.06 & 0.0 & 1.94 \\
\hline Pf & 2.31 & 2.29 & 2.30 & 2.27 & 2.31 & 2.30 & 2.31 & 2.30 & 2.31 \\
\hline $\mathrm{Sm}$ & 0.0 & 0.0 & 0.0 & 0.0 & 0.0 & 0.0 & 0.0 & 0.0 & 0.0 \\
\hline $\mathrm{Pm}$ & 0.42 & 0.48 & 0.42 & 0.34 & 0.32 & 0.34 & 0.34 & 0.48 & 0.44 \\
\hline Ap & 0.03 & 0.02 & 0.03 & 0.02 & 0.03 & 0.03 & 0.03 & 0.03 & 0.03 \\
\hline $\mathrm{Cc}$ & 0.0 & 0.0 & 0.0 & 0.0 & 0.0 & 0.0 & 0.0 & 0.0 & 0.0 \\
\hline \multicolumn{10}{|c|}{ Normative Per Cent (Residual System) } \\
\hline${ }^{* *} \mathrm{Q} \mathrm{Z}$ & 34.96 & 33.49 & 31.82 & 34.28 & 33.85 & 32.32 & 33.34 & 31.98 & 34.51 \\
\hline **Or & 31.34 & 22.19 & 21.49 & 22.35 & 32.03 & 26.40 & 21.63 & 22.96 & 18.49 \\
\hline$* A b$ & 33.70 & 44.33 & 46.69 & 43.37 & 34.12 & 41.28 & 45.03 & 45.06 & 47.01 \\
\hline $2 z^{* *}$ & 33.16 & 32.33 & 30.85 & 33.00 & 32.31 & 31.36 & 32.26 & 30.96 & 32.97 \\
\hline Dr** & 29.73 & 21.42 & 20.84 & 21.52 & 30.57 & 25.61 & 20.93 & 22.23 & 17.67 \\
\hline Ab** & 31.97 & 42.80 & 45.26 & 41.75 & 32.57 & 40.05 & 43.58 & 43.63 & 44.91 \\
\hline $\mathrm{An} * *$ & 5.14 & 3.46 & 3.06 & 3.73 & 4.55 & 2.98 & 3.23 & 3.18 & 4.45 \\
\hline
\end{tabular}

surrounds the feldspars, as well as a late, brown phase which may be oxydized aenigmatite. About 20 per cent late quartz is present. This granite fragment could be the plutonic equivalent of the rhyolitic glass found in the overlying ash layers (Figures 5 and 6).

\section{CHEMICAL DATA}

Two samples were selected from Holes 407 and 408 for chemical analysis. Sample 407-10-3, $50 \mathrm{~cm}$ (Sample A) is from the mid-Pliocene layer and Sample 408-21, CC (Sample B) is from the mid-Miocene layer. Both have a composition of meta-aluminous alkali rhyolite (Table 1), and plot in the minimum region of the residual system of Tuttle and Bowen (1958). Figure 7 shows that the analyzed glass from Hole 408 and some of the glasses of Hole 407 (those with less normative quartz) compare with rhyolite compositions from Icelandic central volcanoes, e.g., Thingmuli (Carmichael, 1964). According to Carmichael, these are derived by fractionation from a tholeiitic magma. 


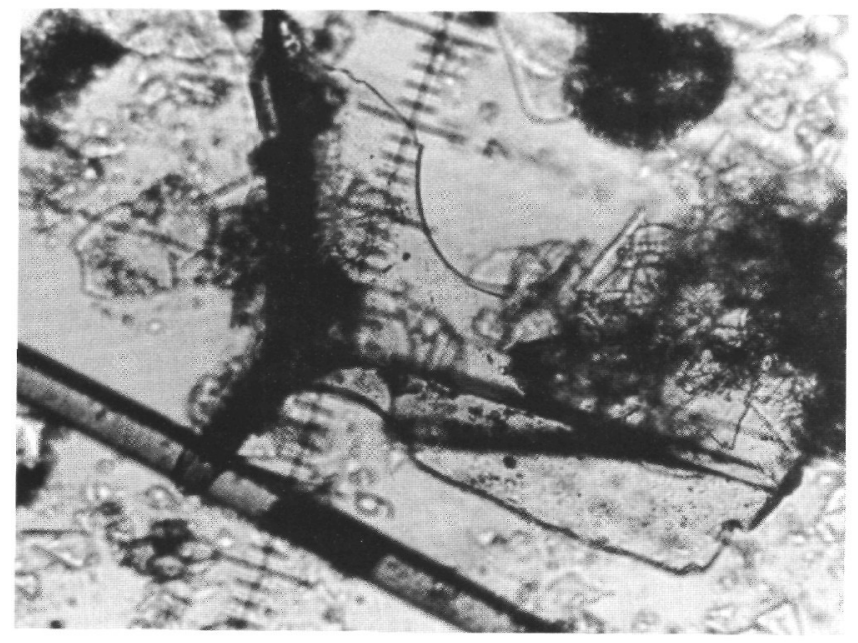

Figure 5. Detailed photograph of a rhyolitic glass fragment. Morphology indicates that fragmentation is result of vesiculation.

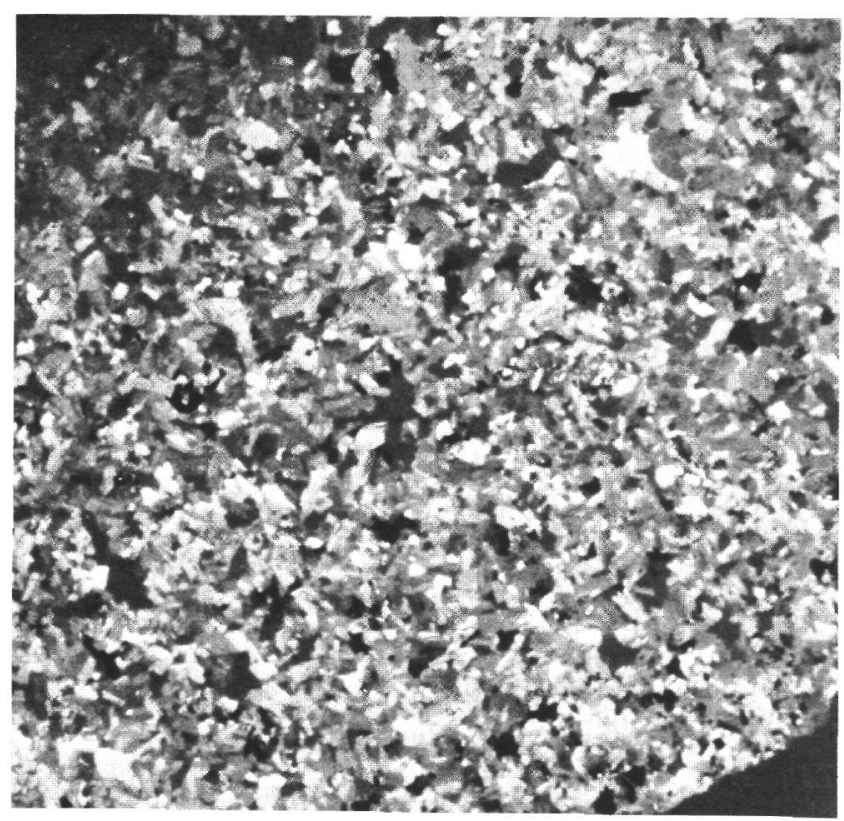

Figure 6. Photograph of the fragment of alkoligranite recovered from ash-rich layers in Hole 408 (X 5).

In the case of glasses analyzed from Leg 49, and in particular those of Hole 407, glass compositions lie along a trend which is strikingly parallel to the quartz-feldspar cotectic of Tuttle and Bowen (1958) for 1000 bars. Some of the analyses plot on the potassic feldspar side of the minimum. This may indicate that the analyzed rhyolitic glasses do not result from a simple crystal fractionation process, but are better explained by partial melting at a pressure of nearly 1000 bars. A similar process was proposed by Gibson (1969) for Icelandic pitchstones (i.e., 3 $\mathrm{km}$ depth). Further mineralogical and geochemical work is needed before this evidence can be considered conclusive, and the nature of the parent material defined.

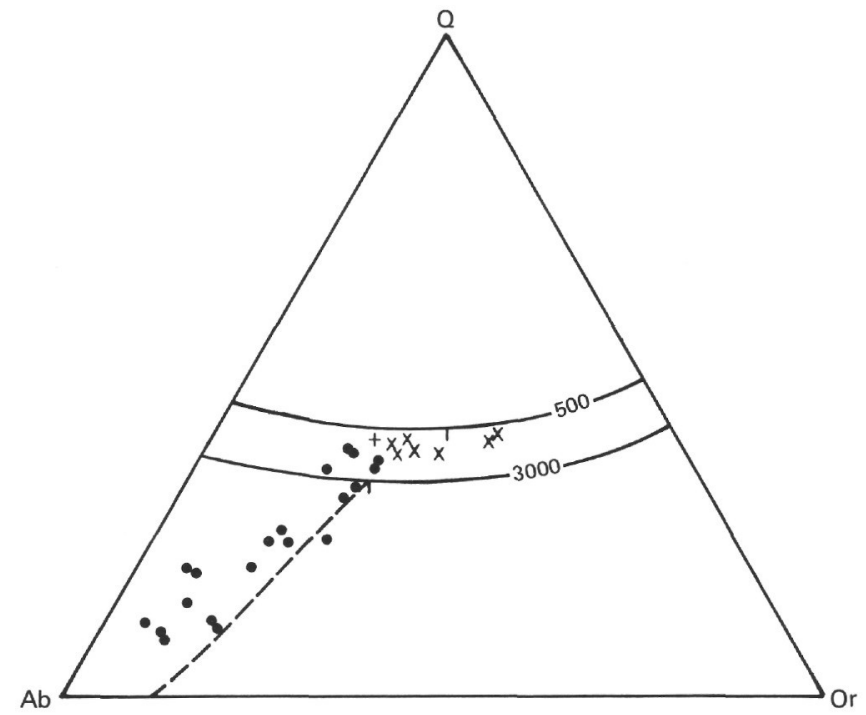

Figure 7. Plot of the composition of rhyolitic glasses from Holes 407 and 408 on a normative quartz-orthoclasealbite diagram. The Thingmuli series (Carmichael, 1964) is reported for comparison (dots and filled circles for rhyolites), as well as the Skaergaard trend (Wager, 1960). The boundary curves and minima at 500 and 3000 bars water vapor pressure also shown (Tuttle and Bowen, 1958). (x) analysis of glasses from Hole 407, (+) analysis of glass from Hole 408 (see Table 1).

The occurrence of rhyolitic ash layers in Hole 407 and 408 , as well as in the granitic block found in the nearby core from Hole 408, can be added to previous descriptions of rhyolitic products in oceanic environments (Baker and MacReath, 1972). Until now, rhyolitic flows have never been recovered from DSDP cores; basalt is considered the typical volcanic product from oceanic environment. It is possible that rhyolitic activity is more frequent than previously considered for the ocean floor, and that the eruptive mechanisms in submarine conditions favor the formation of clastic products dispersed on the sea floor rather than lava flows of more limited extension.

\section{DISCUSSION}

Petrographic observations show that both basaltic and rhyolitic glasses constitute the ash layers intercalated in the sediments of Holes 407 and 408. Major-element chemical analysis, made using the Camebax microprobe of Cameca at Orsay University, show that brown glass from Sample 21, $\mathrm{CC}$, Hole 408, is a tholeiitic basalt low in potassium. Clear glass is alkali-rhyolitic.

The origin of these glasses cannot be defined at this stage. They may well originate from Icelandic volcanoes, but also may be erupted from submarine central volcanoes located south of Iceland. The analogy between granitic blocks and rhyolitic glasses found at a similar stratigraphic level may indicate that both products have a common origin. Further study of the aerial distribution of ashes in the Iceland region is needed to define the geographic origin of these products of violent volcanic eruptions. Further mineralogical and geochemical analysis is required to determine the petrogenesis of these products. 


\section{REFERENCES}

Baker, P.E. and McReath, I., 1972. The acid rocks of the ocean basins, Bull. Volcanol. v. 36, p. 328-341.

Carmichael, I.S.E., 1964. The petrology of Thingmuli, a tertiary volcano in Eastern Iceland, J. Petrol., v. 5, p. 435-460.

Gibson, I.L., 1969. Origin of some icelandic Pitchstones, Lithos, v. 2, p. 343-349.
1970. Discussion and reply, Lithos, v. 3, p. 369-373.

Tuttle, O.F. and Bowen, N.L., 1958. Origin of granite in light of experimental studies in the system $\mathrm{Na} \mathrm{Al} \mathrm{Si}_{3} \mathrm{O}_{8}-\mathrm{K} \mathrm{Al} \mathrm{Si}_{3}$ $\mathrm{O}_{8}-\mathrm{SiO}_{2}-\mathrm{H}_{2} \mathrm{O}$, Geol. Soc. Am. Mem. v.74, p. 153.

Wager, L.R., 1960. The major element variation of the layered series of the Skaergaard intrusion and a re-estimation of the average composition of the hidden layered series and of the successive residual magmas, J. Petrol., v. 1, p. 364-98. 